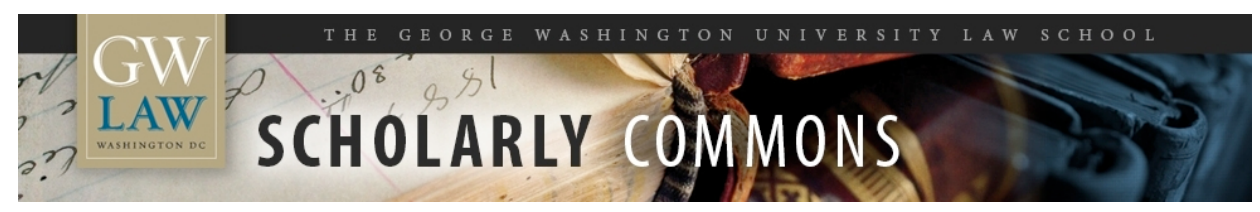

\title{
Berkshire Versus KKR: Intermediary Influence and Competition
}

Lawrence A. Cunningham

George Washington University Law School, lacunningham@law.gwu.edu

Follow this and additional works at: https://scholarship.law.gwu.edu/faculty_publications

Part of the Law Commons

\section{Recommended Citation}

Cunningham, Lawrence A., Berkshire Versus KKR: Intermediary Influence and Competition (2015). GWU Law School Public Law Research Paper No. 2015-40; Appearing in University of Chicago Law Review Dialogue (2015) ; GWU Law School Public Law Research Paper No. 2015-40; GWU Legal Studies Research Paper No. 2015-40. Available at SSRN: http://ssrn.com/abstract=2669547

This Article is brought to you for free and open access by the Faculty Scholarship at Scholarly Commons. It has been accepted for inclusion in GW Law Faculty Publications \& Other Works by an authorized administrator of Scholarly Commons. For more information, please contact spagel@law.gwu.edu. 


\title{
Berkshire versus KKR:
}

\section{Intermediary Influence and Competition}

\author{
Lawrence A. Cunningham $\dagger$
}

\section{INTRODUCTION}

The American financial services industry employs innumerable intermediaries working for investors and savers, such as accountants, advisors, agents, bankers, brokers, consultants, directors, funds, lawyers, managers, and rating agencies. They charge considerable fees to facilitate exchanges by easing search and synthesizing or validating complex information. Their influence has been studied from numerous perspectives, including behavioral finance, ${ }^{1}$ industrial economics, ${ }^{2}$ and public-choice theory. ${ }^{3}$ Such treatments illuminate why financial intermediaries exist, what value they add, and what costs they impose, from the perspective of how clients act, how market structures work, and how laws and policies are formulated.

To this substantial literature comes a welcome supplementIntermediary Influence-thanks to Professor Kathryn Judge. Providing a singular account of intermediary influence as a source of sustained pricing power, Judge's article warns of excessive transaction costs, a net direct loss to the constituents of intermediaries (on both sides), and an indirect net social loss. ${ }^{5}$

$†$ Henry St. George Tucker III Research Professor, George Washington University Law School.

1 See generally, for example, Ronald J. Gilson and Jeffrey N. Gordon, The Agency Costs of Agency Capitalism: Activist Investors and the Revaluation of Corporate Governance Rights, 113 Colum L Rev 863 (2013).

2 See generally, for example, Rosemary L. Batt and Eileen Appelbaum, The Impact of Financialization on Management and Employment Outcomes (Upjohn Institute, Feb 2013), archived at http://perma.cc/ACG5-QL56.

3 See generally, for example, John C. Coffee Jr, The Political Economy of DoddFrank: Why Financial Reform Tends to Be Frustrated and Systemic Risk Perpetuated, 97 Cornell L Rev 1019 (2012).

5 Kathryn Judge, 82 U Chi L Rev 573, 624-630 (2015).

Intermediary Influence, 
Such an outcome is in tension with prevailing thought in microeconomics, which prescribes and predicts that market forces spontaneously and inexorably pressure for transaction cost minimization. ${ }^{6}$

After all, as Professor Ronald Coase taught nearly a century ago, rational economic actors will self-rely when the costs of intermediation exceed the gains. This is the rationale for the existence of firms: they organize economic activity. ${ }^{7}$

Economists dating to the writing of Coase's seminal work, The Nature of the Firm, assume that institutional arrangements evolve to minimize transaction costs, yet Judge highlights how the influence of financial intermediaries often produces persistently high transaction costs. Her intuition is that contemporary transaction costs are heavy with fees charged by intermediaries who seek to maximize economic gain in settings in which their expertise and positions enable them to promote institutional arrangements that yield high fees despite the existence of lower-cost alternatives. ${ }^{8}$

Judge uses examples from several contexts-those of real estate agents, ${ }^{9}$ stockbrokers, ${ }^{10}$ mutual funds, ${ }^{11}$ and stock exchanges ${ }^{12}$ - to illustrate how intermediary influence is accumulated and wielded. While acknowledging that financial intermediaries often add value and earn fees commensurate with benefits, Judge simultaneously explains how the phenomenon of intermediary influence should be incorporated into theories of economic behavior and explores how market participants and policymakers might respond in high-fee environments. ${ }^{13}$ Among the various important responses are competitive or regulatory

6 See Elizabeth Hoffman and Matthew L. Spitzer, The Enduring Power of Coase, 54 J L \& Econ S63, S64 (2011) (stating that "almost every field of economics and political science is shaped by Coasean [transaction cost theory] insights"). See also generally Jason Scott Johnston, The Influence of The Nature of the Firm on the Theory of Corporate Law, 18 J Corp L 213 (1993) (examining the widespread influence and adoption of Coase's transaction cost theory in the field of corporate law). But see Anoop Madhok, Reassessing the Fundamentals and Beyond: Ronald Coase, the Transaction Cost and Resource-Based Theories of the Firm and the Institutional Structure of Production, 23 Strategic Mgmt J 535, 535-36 (2002) (analyzing a resource-based theory of firm activity in tension with Coase's transaction cost-minimization theory).

7 See R.H. Coase, The Nature of the Firm, 4 Economica 386, 390-98 (1937).

8 Kathryn Judge, Intermediary Influence, 82 U Chi L Rev 589-90 (2015).

9 See id at 583-88.

10 See id at $600-01$.

11 See id at 602-10.

12 See Judge, 82 U Chi L Rev at 598-600 (cited in note 8).

13 See id at 635-42. 
tools that increase transparency, enabling participants to shop comparatively in order to avoid excessive fees. ${ }^{14}$

In this Essay, I offer an additional context-the acquisitions market-in which intermediary influence manifests itself yet is accompanied by potential competitive and regulatory pressures of the kind Judge envisions constraining excessive fees. In this market, acquirers are diverse, and they include financial bidders such as private equity firms as well as strategic buyers like rivals in similar sectors and diversifying conglomerates. These acquirers' propensities to use intermediaries and generate costs vary: many incur significant and frequent fees, while others eschew them. Sellers of businesses-and others affected by the acquisition process, including shareholders, lenders, employees, and other stakeholders-face radically different cost structures.

The acquisition industry is characterized by the traits that, as Judge shows, typify intermediary influence: transaction constituents are often one-time players who rely heavily on acquisition intermediaries. ${ }^{15}$ These intermediaries are in turn repeat players in oligopolistic markets who engineer complex, opaque transactions that require specialized knowledge. ${ }^{16}$ But the industry is not limited to intermediaries wielding influence and earning high fees; it also includes rivals who keep costs low. This Essay highlights two powerhouses representing opposite ends of the spectrum of financial intermediation: Berkshire Hathaway, the conglomerate built by Warren Buffett that eschews financial intermediation, and Kohlberg Kravis Roberts (KKR), the pioneering private equity firm that thrives on such intermediation. The juxtaposition illustrates both the intermediary influence that Judge describes and the efficacy of her prescription to counter it with transparent low-cost rivals.

After presenting this comparison and drawing related implications, this Essay offers broader reflections on Judge's work, principally by posing four questions: How much should we expect financial intermediaries' fees to decline due to technological advances in light of countervailing factors such as globalization and complexity that may sustain high fees? Is it feasible to distinguish the influence on institutional arrangements of specific intermediaries from the influence and effects of other participants? Is intermediary influence invariably exerted to benefit primarily intermediaries or instead to aid

\footnotetext{
14 See id at 638 .

15 See id at $614-16$.

16 See Judge, 82 U Chi L Rev at 618-20 (cited in note 8).
} 
producers or even consumers? And can the causal arrow be discerned-that is, is it clear that certain institutional arrangements exist because of intermediary influence, or might institutional arrangements such as oligopolistic industry structures cause the influence? This Essay stresses that, far from constituting criticism of Judge's work, such questions warrant further research precisely because her work is so important and fruitful.

\section{The PROMIse OF LOW-Cost RIVALS}

A Wall Street saying quips that while transactions generate fees, fees often generate transactions. An acute example occurs when a company is encouraged to make an acquisition to diversify and gain synergies, only to be later encouraged to divest the business to unify focus and to shed the shackles of bureaucracy. In the world of private equity epitomized by KKR, it is common to see the same company bought and sold multiple times over a decade or so, generating considerable repeat fees for the intermediaries who design and administer such transactions. ${ }^{17}$

While conglomerates sometimes follow the buy-and-flip approach, strategic buyers (and Berkshire, to a fault) generally prefer a buy-and-hold route with fewer intermediaries and lower costs. ${ }^{18}$. As competitors in the acquisition market, it should be possible for Berkshire and other strategic buyers to dampen the fees of KKR and other private equity firms, at least if there are enough participants and if fees are disclosed for scrutiny. Neither condition currently prevails, but policy might be nudged in those directions.

\section{A. Anti-intermediation: Berkshire Hathaway ${ }^{19}$}

Berkshire-a fifty-year-old conglomerate under Buffett's leadership and now America's third-largest public company-

17 See Steven N. Kaplan and Per Strömberg, Leveraged Buyouts and Private Equity, 23 J Econ Persp 121, 129 (2009) (finding that "secondary buyouts"-sales from one private equity firm to another-are the second most common investment exit method).

18 See George P. Baker and George David Smith, The New Financial Capitalists: Kohlberg Kravis Roberts and the Creation of Corporate Value 168 (Cambridge 1998) ("The documented behavior of successful conglomerates shows that they tended to be opportunistic buyers but reluctant sellers of companies. So long as constituent business units continued to meet minimal corporate performance criteria, they were unlikely to be sold.").

19 For additional analysis of Berkshire, see generally Lawrence A. Cunningham, Berkshire's Disintermediation: Buffett's New Managerial Model, 50 Wake Forest L Rev (forthcoming 2015) (examining Berkshire's anti-intermediation policies and suggesting 
almost never uses intermediaries. Despite being held by approximately one million shareholders and boasting a market capitalization nearing half a trillion dollars, ${ }^{20}$ it has scarcely borrowed money; ${ }^{21}$ despite being built through the serial acquisition of some seventy subsidiaries over fifty years, Berkshire has rarely hired a business broker;23 and despite employing nearly 350,000 people, ${ }^{24}$ it hardly ever uses consultants of any kind. ${ }^{25}$ As Berkshire's vice chairman, Charlie Munger, once explained to me, the company follows these practices because it takes Professor Coase seriously. Why others don't is likely due to a combination of factors, including managerial interests (agency costs), the allure of debt, and legal pressures to reduce liability risk-and also due to intermediary influence.

While American companies borrow heavily to boost returns and gain tax advantages, ${ }^{26}$ Berkshire shuns debt as costly and constraining, preferring to rely on itself and use its own money. ${ }^{27}$ It generates abundant earnings and retains 100 percent of them-it has not paid a dividend in nearly fifty years. ${ }^{28}$ In 2014 , Berkshire's net worth grew by $\$ 18.3$ billion-all of which was available for reinvestment. ${ }^{29}$ Its time horizon is forever because it commits to own its subsidiaries indefinitely-a promise backed

that these policies may shape future generations of similar firms); Lawrence A. Cunningham, Berkshire beyond Buffett: The Enduring Value of Values (Columbia 2014) (examining how Berkshire's distinctive corporate culture informs its success). See also generally Lawrence A. Cunningham, Minus the Middleman: Berkshire Model Offers Profitable Lessons (Omaha World-Herald, May 2, 2015), archived at http://perma.cc/R7WS-GKEE; Lawrence A. Cunningham, The Philosophy of Warren E. Buffett (NY Times, May 1, 2015), archived at http://perma.cc/H7BP-Q285.

20 See Berkshire Hathaway Inc. Cl A (MarketWatch, Sept 11, 2015), archived at http://perma.cc/5VSA-KXT6.

21 See Cunningham, 50 Wake Forest L Rev at *9-10 (cited in note 19).

23 Cunningham, Berkshire beyond Buffett at 213 (cited in note 19).

24 Berkshire 2014 Report at *125 (cited in note 22 ).

25 Lawrence A. Cunningham, Buffett's and Berkshire's Anti-bureaucracy (Columbia Law School, June 17, 2015), archived at http://perma.cc/636E-X8GL.

26 See generally John R. Graham, How Big Are the Tax Benefits of Debt?, $55 \mathrm{~J}$ Fin 1901 (2000). But see generally Jennifer Blouin, John E. Core, and Wayne Guay, Have the Tax Benefits of Debt Been Overestimated?, 98 J Fin Econ 195 (2010).

27 See Berkshire 2014 Report at *118 (cited in note 22) ("We use debt sparingly and, when we do borrow, we attempt to structure our loans on a long-term fixed-rate basis. We will reject interesting opportunities rather than over-leverage our balance sheet."). But see id at *113 ("We also issue debt in the ordinary course of business to fund business operations, business acquisitions and for other general purposes.").

28 See Cunningham, 50 Wake Forest L Rev at *7 (cited in note 19). See also Berkshire 2014 Report at *124 (cited in note 22 ).

29 Berkshire 2014 Report at *3 (cited in note 22 ). 
by a record of not selling one in forth years. ${ }^{30}$ Thanks to its long time horizon, Berkshire's deferred taxes total over $\$ 60$ billion. ${ }^{31}$ These amount to interest-free government loans without covenants.

The principal leverage at Berkshire is insurance float. ${ }^{32}$ This refers to funds that arise because Berkshire receives premiums up front but need not pay claims until later, if it all. ${ }^{33}$ Provided that insurance is underwritten with discipline, float is akin to borrowed money but cheaper, and it comes without due dates or covenants. ${ }^{34}$ At Berkshire, float now totals $\$ 84$ billion, which is used to buy businesses that continue to multiply Berkshire's value. $^{35}$

All these sources of funds can be transferred among Berkshire subsidiaries, so those with excess cash support those with capital needs - all tax free and without the frictional costs of debt. ${ }^{36}$ Berkshire and its subsidiaries become self-reliant, selfdisciplining financing machines. (Two of Berkshire's capitalintensive subsidiaries, a railroad and a public utility, borrow significant sums, but none of their debt is guaranteed by Berkshire. ${ }^{37}$ )

American corporations rely heavily on intermediaries, such as business brokers and investment bankers, who charge fees and have incentives to get deals done; firms also use accountants, consultants, and lawyers to conduct due diligence before closing. Berkshire rarely uses bankers or brokers, and it does limited due

30 Cunningham, The Philosophy of Warren E. Buffet (cited in note 19) ("Unique among its rivals in the acquisition market, Berkshire has not sold a subsidiary in 40 years, and pledges not to do so unless a business is doomed.”); Berkshire 2014 Report at *119 (cited in note 22 ):

Regardless of price, we have no interest at all in selling any good businesses that Berkshire owns. We are also very reluctant to sell sub-par businesses as long as we expect them to generate at least some cash and as long as we feel good about their managers and labor relations.

31 Berkshire 2014 Report at *72 (cited in note 22).

32 Andrea Frazzini, David Kabiller, and Lasse H. Pedersen, Buffett's Alpha *11-12 (National Bureau of Economic Research, Nov 2013), archived at http://perma.cc/82JUDHF8 (identifying Berkshire Hathaway's "two main liabilities [as] debt and insurance float ... [with] 36\% of Berkshire's liabilities consist[ing] of insurance float on average.”).

33 See id at *12.

34 Berkshire 2014 Report at *119 (cited in note 22 ).

35 Id at *8.

36 See Cunningham, 50 Wake Forest L Rev at *10-11 (cited in note 19).

37 See Cunningham, 50 Wake Forest L Rev at *10 n 38 (cited in note 19) (identifying Burlington Northern Santa Fe and Berkshire Hathaway Energy together as accounting for $\$ 55$ billion of Berkshire's $\$ 74$ billion total debt); Berkshire 2014 Report at *12 (cited in note 22 ). 
diligence. ${ }^{38}$ Instead, Berkshire relies on a network of relationships, including previous sellers of businesses. ${ }^{39}$ Buffett is self-reliant, thanks to gargantuan reading that gives him broad business knowledge and an investment philosophy that values companies based on old-fashioned business analysis rather than market-based proxies such as price-earnings multiples. ${ }^{40}$

Most acquirers of businesses promptly implement operational changes and related engineering to integrate a business, find synergies, and cut costs. Berkshire acquires only companies for which no such changes are needed, and it never pursues such a strategy. ${ }^{41}$

Indeed, contrary to the practice at most sizable American corporations, Berkshire has no centralized procedures or departments, no hierarchies for reporting or budgeting, and no middle managers. ${ }^{42}$ All such functions are handled in the individual units. In fact, Berkshire headquarters employs just twenty-five people. ${ }^{43}$ And Berkshire gives CEOs of its subsidiaries almost unbridled discretion over operations. ${ }^{44}$ Once a year, Buffett sends them the same one-page letter with six broad mandates on it, such as "protect Berkshire's reputation" and "report bad news early." "Many speak to Buffett only once a year-others less often." 46

38 See Lawrence Cunningham, Cunningham: Why Don't More Companies Copy the Berkshire Model? (Omaha World-Herald, May 2, 2015), archived at http://perma.cc/RJ693V5Q; Cunningham, 50 Wake Forest L Rev at *12-13 (cited in note 19) (providing examples of Berkshire's limited use of intermediaries in its acquisitions).

39 See Robert E. Miles, The Warren Buffett CEO: Secrets from the Berkshire Hathaway Managers 344 (Wiley 2002).

40 See id at 342 .

41 See Berkshire 2014 Report at *40 (cited in note 22) (describing the Berkshire acquisition policy as "seek[ing] to pay a fair price for a good business that the Chairman could pretty well understand"). The rare exceptions occurred early in Buffett's career, such as the 1977 acquisition of The Buffalo News, which faced considerable competitive pressure. See Miles, The Warren Buffett CEO at 235 (cited in note 39).

42 See Berkshire 2014 Report at *86 (cited in note 22 ).

43 Id at *6, 125 .

44 See Berkshire Hathaway Inc.: 2009 Annual Report *5 (2010), archived at http://perma.cc/9FVJ-8KW8 ("We tend to let our many subsidiaries operate on their own, without our supervising and monitoring them to any degree.").

45 Cunningham, 50 Wake Forest L Rev at *9 (cited in note 19).

46 Cunningham, Buffett's and Berkshire's Anti-bureaucracy (cited in note 25). See also Miles, The Warren Buffett CEO at vi (cited in note 25) ("Warren's CEOs do not have to call Omaha daily or provide weekly reports. . . Of course, most of them want to talk to Buffett and check in periodically. But they don't have to.”). 
Today, corporate America's boards are intermediaries between shareholders and management. ${ }^{47}$ Directors are monitors involved in specific strategic decision making. ${ }^{48}$ They meet monthly, using many committees, ${ }^{49}$ which in turn hire accountants, consultants, and lawyers. American directors are well paid, averaging salaries of $\$ 263,748$ annually-including considerable stock compensation and company-purchased liability insurance. ${ }^{50}$ Berkshire's board, in contrast, follows the old-fashioned advisory model: It is comprised of friends and family, who are directors because they are interested in Berkshire. ${ }^{51}$ They do not oversee management, but rather provide support and advice. There are few committees, no hired advisors, and only two or three meetings per year. ${ }^{52}$ Berkshire pays its directors essentially nothing and provides no insurance. ${ }^{53}$ But Berkshire's directors are significant shareholders, each of whom bought the stock with their own cash. ${ }^{54}$

As Judge notes, most American corporate equity is owned by large financial intermediaries such as mutual funds, hedge funds, and pension funds. ${ }^{55}$ Stock trading is frequent and portfolios are regularly rebalanced to maintain diversification. As Judge observes, this generates significant fees for intermediaries as well as frictional costs for investors. ${ }^{56}$ Most of Berkshire's shareholders either own the stock directly-individuals, families, and family offices - or hold it through family-oriented firms that concentrate in Berkshire stock. ${ }^{57}$ Berkshire's share turnover is low and is

47 See Jeffrey N. Gordon, The Rise of Independent Directors in the United States, 1950-2005: Of Shareholder Value and Stock Market Prices, 59 Stan L Rev 1465, 1468 (2007).

48 See id at 1506.

49 See id at $1490-94$.

50 See 2014 Spencer Stuart Board Index *35 (Spencer Stuart 2014), archived at http://perma.cc/8L5J-4PSZ.

51 See Andrew Kilpatrick, Of Permanent Value: The Story of Warren Buffett 164 (McGraw-Hill rev ed 1998) ("Berkshire's board is small, family-oriented and has no real outside directors.").

52 See id at 163 ("In keeping with its lean structure carefully devised by Buffett, there are only seven directors on the board, which has no standing committees and gets little in the way of outside advice.").

53 See Berkshire 2014 Report at *36 (cited in note 22) (describing Berkshire's directors' fees as "token" and claiming that Berkshire carries "no directors and officers liability insurance").

54 See id.

55 Judge, 82 U Chi L Rev at 602 (cited in note 8) (noting that institutional investors owned more than "76 percent of the outstanding equity for 1,000 largest corporations").

56 Id at 605-06.

57 See Cunningham, 50 Wake Forest L Rev at *6 (cited in note 19). 
many shareholders' largest holding. ${ }^{58}$ All this minimizes the role and costs of intermediaries, from stockbrokers to exchanges.

Corporations are hierarchies, with shareholders owning a residual claim on firm assets in the form of an equity stake after liabilities are covered by assets. That inherent separation of ownership from control provides a fertile environment for financial intermediaries to flourish. ${ }^{59}$ In contrast, Buffett defines Berkshire as a partnership, declaring from the outset: "Although our form is corporate, our attitude is partnership." 60 This is a legacy from Buffett's start: he was running a partnership that, in 1965, acquired Berkshire, which then began acquiring other companies en route to becoming the galactic corporation it is today. ${ }^{61}$ Buffett retained that partnership spirit, a profound disintermediation that views the corporation as a conduit through which shareholders own its assets and not merely an equity stake. ${ }^{62}$ Such conceptions are the polar opposite to the chain of intermediation in many contemporary financial sectors that Judge criticizes. ${ }^{63}$

Most corporate boards set their dividend policies to follow a regular periodic amount invariant to business conditions and split the stock when price exceeds an affordable trading range in order to keep shareholders interested in trading it. ${ }^{64}$ Berkshire's dividend policy varies with corporate ability to reinvest earnings profitably, which has meant no dividends since 1969; it has polled shareholders on whether they approve of this policy (they do). ${ }^{65} \mathrm{It}$ doesn't split the stock to keep the price low. On the contrary, consider a spectacular example of Berkshire's antiintermediation policy: In 1996, when Berkshire's stock traded at $\$ 34,900$, two money managers designed a unit trust that would buy the stock and issue fractional units designed to trade at a low price. They would charge fees for this service that would draw new traders to Berkshire, increasing transaction costs. To knock out these middlemen, Berkshire amended its charter to rename its existing common stock as Class A and add a Class B with

\footnotetext{
58 See Cunningham, Berkshire beyond Buffett at 37 (cited in note 19).

59 See Jill E. Fisch, Securities Intermediaries and the Separation of Ownership from Control, 33 Seattle U L Rev 877, 879-884 (2010).

60 Berkshire 2014 Report at *36 (cited in note 22 ).

61 See id at *24-28.

62 See id at* 117 .

63 See Judge, 82 U Chi L Rev at 624-30 (cited in note 8).

64 See Cunningham, 50 Wake Forest L Rev at *7 (cited in note 19).

65 See Berkshire 2014 Report at *38 (cited in note 22) (describing a tally of proxy votes in which 98 percent of the shares represented voted to keep the no-dividend policy).
} 
fractional rights. ${ }^{66}$ It vowed to offer as many shares as necessary to fill orders-which it did, killing demand for the unit trust. ${ }^{67}$

Berkshire's savings from omitting the middleman include the direct costs of fees and interest plus the vastly larger indirect costs of relying on advisors whose incentives are to encourage more action-more debt, deals, trading, services, and fees. While Buffett and Munger are responsible for much of this practice, it has been internalized across the institution and is likely to endure after successors assume control. 68 The more interesting question is not whether such habits can endure at Berkshire but rather why they are not more widely practiced. Judge is right to explain that intermediary influence is a factor-consequently, public policy should be designed to encourage proliferation of the Berkshire model.

\section{B. Pro-intermediation: Kohlberg Kravis Roberts}

KKR - a forty-year-old leveraged buyout firm and the historical driving force behind today's massive private equity industry - is both an intermediary and a progenitor of intermediaries. ${ }^{69}$ Its business model and philosophy are at the other end of the spectrum from that of Berkshire in nearly every important way. Having arranged for the purchase and sale of thousands of companies, it has structured mountains of debt, generated enormous fees from merger advisory services in thousands of transactions, and reaped additional gains from innumerable advisory and consulting services. ${ }^{70}$

KKR's business model involves creating a series of separate funds that buy, run, and sell a discrete number of individual companies, relying throughout on massive borrowing. ${ }^{71}$ A typical fund deal is financed with at least 70 percent debt. ${ }^{72}$ Moreover, virtually all equity-all but 1 to 5 percent-is staked not by the firm but by outside investors and solicited in private placements facilitated by intermediaries, including pension plans, university endowments, sovereign wealth funds, banks, and insurance

66 Robert W. Hamilton, Reflections on the Pricing of Shares, 19 Cardozo L Rev 493, 500-01 (1997).

67 See id at 503.

68 Cunningham, Minus the Middleman (cited in note 19).

69 See Eileen Appelbaum and Rosemary Batt, Private Equity at Work: When Wall

Street Manages Main Street 21-24 (Russell Sage Foundation 2014).

70 See id at 24-27.

71 Baker and Smith, The New Financial Capitalists at 168-69 (cited in note 18).

72 Appelbaum and Batt, Private Equity at Work at 2 (cited in note 69). 
companies. ${ }^{73}$ In form, funds are dubbed "partnerships," with KKR as the general partner and each such equity investor a limited partner; but the attitude is hierarchical, with the general partner calling all the shots in a setting rife with conflicts of interest. ${ }^{74}$

As general partner, KKR is less an investor than a multiline intermediary. As an intermediary, KKR collects 2 percent of investors' equity through a "management fee," plus 20 percent of the return on investment above a hurdle rate (typically 8 percent), which is dubbed "carried interest." 75 In addition, the intermediary can levy extensive fees for a wide variety of activities that it might engineer, such as board service on acquired companies, strategic consulting, executive search, merger advice, or arrangement of debt financing. ${ }^{76}$ Intermediary influence in such settings is enormous and essentially uncheckable, with the press being among the few bulwarks against excess. ${ }^{77}$

KKR's time horizon for deals is short- or medium-term, not long-term-and never indefinite. Rather, purchases and subsequent steps are all conducted with a focus on exiting by maximizing profits and minimizing duration. ${ }^{78}$ Purchases are not made without an exit strategy-ideally a premium-priced public offering orchestrated by the intermediary or an arranged sale to a strategic buyer or another financial buyer. ${ }^{79}$ As with most other

73 See Matthew D. Kain, Stephen B. McKeon, and Steven Davidoff Solomon, Intermediation in Private Equity: The Role of Placement Agents * 15,35 (unpublished manuscript, May 2015), archived at http://perma.cc/6S9E-TZKQ (analyzing the common categories of external investors); Ryan Kantor and Ryan Sullivan, A Lawyers Guide: Valuation Issues in Private Equity Funds *2 (unpublished manuscript, Dec 6 2012), archived at http://perma.cc/9SB3-L9UB (placing the amount of investment capital provided by private equity managers between 1 and 5 percent).

74 See Kantor and Sullivan, A Lawyers Guide at *2-4 (cited in note 73) (noting that "[i]nvestors don't participate at all in the management of the fund," and that "[t]here are certain inherent and potential conflicts of interest between the funds sponsor on one hand and the fund and investors on the other").

75 See David A. Weisbach, The Taxation of Carried Interests in Private Equity, 94 Va L Rev 715, 722-23 (2008).

76 See Andrew Metrick and Ayako Yasuda, The Economics of Private Equity Funds, 23 Rev Fin Stud 2303, 2314 (2010).

77 See, for example, Gretchen Morgenson, The Deal's Done. But Not the Fees (NY Times, May 24, 2014), archived at http://perma.cc/E3WM-DZSW (highlighting the high fees obtained by private equity firms, some of which have been described as "undetectable by even the most sophisticated investor," and serving as an example of the press's ability to shed light on these types of arrangements).

78 See Guy Fraser-Sampson, Private Equity as an Asset Class 9-11 (Wiley 2007) (discussing the limited nature of a private equity fund's investments due to the limited partnership structure that they take).

79 See Kaplan and Strömberg, 23 J Econ Persp at 129 (cited in note 17) (showing public offerings and sales to strategic buyers or other financial buyers as the most common exits). 
activities that KKR conducts on behalf of the funds and companies it buys, the firm charges fees for making such arrangements. ${ }^{80}$ When buying and selling, KKR and other private equity firms favor formal valuation models, such as earnings multiples, rather than traditional business analysis of the kind that Berkshire and other long-term investors apply. ${ }^{81}$

Operational change is usually part of every takeover plan. While KKR and other leveraged buyout operators may look for incumbent managers to remain in place, weak management is often blamed for a target's struggles, and the takeover includes reshuffling or replacing the management. ${ }^{82}$ In every case, intervention is deep, as the intermediary provides close direction to managers to execute the plan and conducts careful monitoring to ensure execution. ${ }^{83}$ Cost reductions are often part of the plan, meaning that the intermediary directs not only management changes but also plant closings, layoffs, research and development cuts, product terminations, pension reductions, and other radical business surgeries with clear-cut short-term gains. ${ }^{84}$ The long-term prudence of such steps is generally not considered. ${ }^{85}$

Financial engineering is at the heart of many KKR deals, all involving substantial and costly intermediation. ${ }^{86}$ Often pejoratively dubbed "asset stripping," standard examples are

80 See id at 124.

81 Fraser-Sampson, Private Equity as an Asset Class at 192-93 (cited in note Error! Bookmark not defined.) (describing how buyout firms perform "full financial due diligence . . . includ[ing] commissioning a report from an investigating accountant").

82 See Kaplan and Strömberg, 23 J Econ Persp at 131-32 (cited in note 17) (“[P]rivate equity investors do not hesitate to replace poorly performing management. ... [O]ne-third of chief executive officers of these firms are replaced in the first 100 days while two-thirds are replaced at some point over a four-year period.”).

83 See id at 131 ("[P]rivate equity investors control the boards of their portfolio companies and are more actively involved in governance than public company boards.”).

84 See id at 132 :

Private-equity firms use their industry and operating knowledge to identify attractive investments, to develop value creation plans for those investments, and to implement the value creation plans. A plan might include elements of cost-cutting opportunities and productivity improvements, strategic changes or repositioning, acquisition opportunities, as well as management changes and upgrades.

85 See Kaplan and Strömberg, 23 J Econ Persp at 133 (cited in note 17) (discussing the possibility that the changes implemented by the buyers prioritize short-term over longterm returns).

86 See Baker and Smith, The New Financial Capitalists at 169 (cited in note 18). 
sale-leaseback arrangements ${ }^{87}$ and dividend recapitalizations. ${ }^{88}$ These transactions are designed and implemented by numerous intermediaries operating between the company and investorsintermediaries such as the general partner, leasing agents, lessees, and all their agents (including accountants, bankers, and lawyers). ${ }^{89}$ Each receives compensation for services, the most substantial of which goes to the chief intermediary: the general partner. ${ }^{90}$ In the process, moreover, costs are borne by other constituents of the portfolio companies-including employees, suppliers, customers, communities, and creditors, who are unrepresented by intermediaries. ${ }^{91}$

Since KKR is more an intermediary than an investor, it is inclined toward greater risk taking than an investor would tolerate. High leverage is appealing because the rewards from boosting returns on equity can be considerable, while excessive debt that leads to bankruptcy inflicts little pain. ${ }^{92}$ Whether a company prospers or fails, KKR earns fees for itself and generates fees and interest for other intermediaries, including financial institutions that participate in the process of designing and marketing costly debt. ${ }^{93}$ KKR's intermediary influence is considerable. For example, along with other industry titans, it effected important vocabulary changes commonly used to describe the industry and its principal fuel: the pejorative label "junk bonds" has been successfully replaced with the congenial term "high-yield bonds,"94 and the term "leveraged buyout operator" has been changed to "private equity fund." 95 More measurably,

87 See Appelbaum and Batt, Private Equity at Work at 71-72 (cited in note 69) (describing sale-leaseback arrangements as "sell[ing] the property [of the] company, return[ing] the proceeds to the $\mathrm{PE}$ investors, and then requir[ing] the portfolio company to lease back and pay rent on the property it used to own").

88 Id at 68-71, 286-87.

89 See, for example, id at 74-76 (describing the fallout from the private equity takeover of Hertz, including multiple stock offerings that were handled by intermediaries).

90 Id at 90 ("The 'hierarchy of claims' on the rewards from investing in portfolio companies guarantees that the general partners of [private equity] funds will capture a disproportionate share of the value extracted from these companies.").

91 Appelbaum and Batt, Private Equity at Work at 282 (cited in note 69) ("While workers, vendors, creditors, and companies lost jobs, income, or solvency [in the private equity firm's intervention in several businesses], the PE owners walked away virtually unscathed.").

92 See Batt and Appelbaum, The Impact of Financialization at *27 (cited in note 2).

93 See id at *24.

94 Josh Kosman, The Buyout of America: How Private Equity Is Destroying Jobs and Killing the American Economy 29 (Penguin 2009).

95 See William Alden, Rethinking the Term "Private Equity" (NY Times, Jan 31, 2013). The industry appears to be reconsidering the "private equity" label due to uncertain connotations. See id. 
federal law treats the carried interest that KKR earns as capital gain taxed at 20 percent rather than ordinary income taxed at as much as twice that rate. ${ }^{96}$ Moreover, these intermediaries elude regulatory oversight, despite considerable efforts to increase transparency and control. ${ }^{97}$

Berkshire, in turn, pushes back on intermediaries, including rivals like KKR. Buffett, who has written vigorous indictments of the excessive fees of financial intermediaries, ${ }^{98}$ has publicly and formally objected to specific KKR fees. In 1996, when Buffett served on the board of The Gillette Company-of which Berkshire and its affiliates owned 11 percent-Gillette agreed to acquire KKR's share of Duracell International for $\$ 7.82$ billion in stock. ${ }^{99}$ KKR's bill was double that of Gillette's advisors ${ }^{100}$ (though in line with market pricing), ${ }^{101}$ and Buffett strongly objected to the size of the bill. ${ }^{102}$ Although outvoted by the rest of the board, Buffett went on record as opposing intermediary pricing power. ${ }^{103}$ Berkshire's record is unmistakable.

Despite many differences, Berkshire and KKR are both buyers of businesses and therefore rivals. What they offer to sellers of businesses, however, differs greatly. Berkshire stakes all the capital necessary to offer a permanent autonomous home in a distinctive corporate culture free of short-term pressures. ${ }^{104}$ KKR stakes little funding-borrowing most and bringing in limited partners-and offers an operational and financial plan to deliver rapid and sizable fees to itself along with debt discharge

96 See Victor Fleischer, Two and Twenty: Taxing Partnership Profits in Private Equity Funds, 83 NYU L Rev 1, 14 (2008) (describing how KKR qualifies for this lower tax rate). See also Rande Spiegelman, Taxes: What's New for 2015? (Schwab, Jan 14, 2015), archived at http://perma.cc/ZE4Z-CCX9 (citing the maximum capital gains and income tax rates for 2015 at 20 and 39.6 percent, respectively).

97 See generally Gretchen Morgenson, Private Equity's Free Pass (NY Times, July 27, 2014), archived at http://perma.cc/C9RU-HD2N; Coffee, The Political Economy of Dodd-Frank, 97 Cornell L Rev 1019 (cited in note 3).

98 See Warren E. Buffett and Lawrence A. Cunningham, The Essays of Warren Buffett: Lessons for Corporate America 171-74 (Carolina Academic 3d ed 2013). Munger has bitingly criticized leverage buyouts and junk bonds. See id at 133--34, 208--11.

99 See Buffett Unable to Shave Fees in Duracell Deal (LA Times, Nov 27, 1996), archived at http://perma.cc/P2D4-ZKBZ; Kenneth N. Gilpin, Gillette to Buy Duracell for $\$ 7$ Billion (NY Times, Sept 13, 1996), archived at http://perma.cc/LTW5-FJ7N.

100 See Kilpatrick, Of Permanent Value at 436 (cited in note 51) ("Of the fees, $\$ 10$ million went to [Gillette advisor] Morgan Stanley and Co. and $\$ 20$ million to Kohlberg Kravis Roberts and Co., the buyout firm which owned 34\% of Duracell.”).

101

102 See Buffett Unable to Shave Fees in Duracell Deal (cited in note 99).

103 Id.

104 See Baker and Smith, The New Financial Capitalists at 168 (cited in note 18). 
and returns to outside investors. ${ }^{105}$ Outcomes vary-not all Berkshire companies prosper (although no companies are sold) and KKR has both triumphs and failures (although all companies are sold). ${ }^{106}$ In the popular imagination and among many in the media, the Berkshire model has been preferred over the KKR way-to the consternation of the latter's devotees. ${ }^{107}$

Besides commanding their own fees and returns, KKR and its industry stress returns to shareholders above all else in corporate life-including employees, retirees, suppliers, and customers. ${ }^{108}$ While the Berkshire model is also "investor first"embracing an owner orientation-the long-term focus enables aligning shareholder returns with those of other constituents. Suppose labor costs are high: if the end game is two years, all cuts must be made in two years, necessitating layoffs and wage freezes; but if the horizon is indefinite, cuts can be made gradually over a decade, which might be done with attrition and lower raises. Nor is the Berkshire approach altruistic; rather, it is congruent with generating high and sustained returns on capital for shareholders. The Berkshire model aspires to be winwin.

There are downsides to the Berkshire model. ${ }^{109}$ The selfreliance in acquisitions runs the risk of error given the absence of significant cross-checks. ${ }^{110}$ The autonomy reposed in subsidiary managers sometimes proves misplaced absent vetting or oversight. ${ }^{111}$ The decentralized structure can produce impositions on customers or employees at the hands of other employees or

\footnotetext{
105 See id.

106 Ironically, Berkshire staked funds in one of the largest and worst KKR deals ever, involving TXU Energy, an electric utility, for $\$ 44.37$ billion in 2007 . The deal soon collapsed, causing Berkshire an after-tax loss of nearly $\$ 1$ billion. See Peter Lattman, $\underline{\mathrm{A}}$ Record Buyout Turns Sour for Investors (NY Times, Feb 28, 2012), archived at http://perma.cc/Z8JW-3QAQ.

107 See, for example, Baker and Smith, The New Financial Capitalists at 28-29 (cited in note 18 ).

108 See George Anders, Merchants of Debt: KKR and the Mortgaging of American Business 157-58 (Basic Books 1992) (quoting from private KKR memoranda in 1978 and 1987).

109 See generally Lawrence A. Cunningham, Berkshire's Blemishes: The Visible Costs and Upshot of Buffett's Unique Managerial Model, Columbia Business L Rev (forthcoming March 2016).

110 See id at *6-9.

111 See id at *9-12. See also Edward Greene and Olivia Schmid, Duty-Free Insider Trading?, 2013 Colum Bus L Rev 369, 402 (2013) (describing an investigation against David Sokol, a Berkshire senior executive, for insider trading, in which charges were eventually dropped).
} 
distributors, or of other corporate constituents. ${ }^{112}$ Likewise, KKR acquisitions can yield win-win outcomes in which managers, investors, employees, and others all gain from a transition. But on balance, Berkshire's anti-intermediation has proven spectacularly enriching ${ }^{113}$ and KKR's heavy intermediation is prone to excess for the reasons that Judge stresses. ${ }^{114}$

The differences between Berkshire and KKR reflect a fundamental cultural contrast. In the KKR model, heavy debt and associated covenants and due dates not only boost immediate returns but also "impose[ ] a stringent discipline on management, forcing executives not only to keep costs down, but also to divest any business that might fetch a price higher than the value they had placed on it." 115 Besides not seeking immediate profit boosts, Berkshire's culture requires no such external discipline: Thrift is an inherent value. It induces cost minimization without the need for covenants to impose discipline. And the idea of selling a business is antithetical to the sense of permanence intended to hold Berkshire together in perpetuity. In contrast to the thick corporate culture that pervades Berkshire's subsidiaries, KKR companies have no common corporate culture. ${ }^{116}$

KKR is not a company in the same sense that Berkshire is, nor is it a firm in the sense that Coase used that term. Berkshire is a corporate entity owned by its shareholders and comprises hundreds of operating businesses and other investments to be held indefinitely. ${ }^{117}$ Berkshire is a successful version of the conglomerate business model of the 1970s that firms like KKR participated in dismantling, seeing them as bloated and unfocused.118 Unlike Berkshire, KKR is not a conglomerate organized for perpetual life and has no ability to reallocate capital across its portfolio companies-as Berkshire does across its

112 See Cunningham, Berkshire's Blemishes at *12-14 (cited in note 109). See also Peter Dreier, Human Rights Activists Protest NBA-Linked Sweatshops (Huffington Post, May 25, 2011), archived at http://perma.cc/42NU-SGJX (describing protests against a Berkshire subsidiary employing sweatshops in violation of human rights standards).

113 See Cunningham, Berkshire's Blemishes at *28 (cited in note 109).

114 See Anders, Merchants of Debt at 272-73 (cited in note 84) (discussing the failure of KKR's high-leverage model). See also Judge, $82 \mathrm{U}$ Chi L Rev at 585-588 (cited in note 8) (providing an example of how a prointermediation stance can lead to self-serving behaviors by intermediaries).

115 Baker and Smith, The New Financial Capitalists at 98 (cited in note 18).

116 Id at 100 ("There was certainly no overarching headquarters bureaucracy, and no common corporate culture [among KKR's holdings].”).

117 For a description of Berkshire's business activities, see Berkshire 2014 Report at *45 (cited in note 22). For a list of Berkshire's subsidiaries, see id at *125-27.

118 See Baker and Smith, The New Financial Capitalists at 165-66 (cited in note 18) (describing the conglomerate business model of the 1970s and 1980s). 
subsidiaries. ${ }^{119}$ Rather, KKR consists of a series of distinct limited partnerships organized as equity funds with finite lives of rarely more than a decade. ${ }^{120}$ Unlike conglomerates, which seek to retain the businesses they acquire, KKR desires to divest them profitably and relatively rapidly. ${ }^{121}$ Berkshire prospers from antiintermediation while KKR benefits from prointermediation.

Judge calls for more information to enable constituents to compare the costs of alternative intermediary services. ${ }^{122}$ It would be desirable for sellers of businesses-as well as other constituents - to have greater clarity about the fees associated with private equity transactions offered by KKR and its peers. But if intermediary influence or other forces persist in keeping the industry opaque, competitive rivals such as Berkshire do exert pressure. These rivals should stimulate questions by prospective sellers and entice negotiated reductions by private equity firms. More competition of this sort would therefore be a desirable counterweight to intermediary pricing power.

Few companies exhibit Berkshire's thoroughgoing disintermediation, but tailored versions of the model stress its virtues at such well-known conscious emulators as Markel Corporation ${ }^{123}$ and Leucadia National Corporation. ${ }^{124}$ More recent variations are emerging in the technology sector, especially among companies such as Google in its reorganization as Alphabet Inc., designed on the Berkshire model. ${ }^{125}$ Promising derivations appear among shareholder-activist hedge funds, such as Pershing Square Capital Management, which can meet the goals of some private equity deals-particularly identifying and curing business problems-without incurring acquisition costs. ${ }^{126}$ Allowed or encouraged to flourish, such competition should put downward pressure on private equity fees. They might not

119 See id at 171 ("Nor could KKR transfer cash from one company to another, so that one corporation might support another's operations or investments. Since each investment had separate equity holders, any attempt to intermingle activities in separate companies was fraught with difficulties.").

120 See id at 169-70 (charting KKR's business structure and holding periods for its buyouts).

121 See Kaplan and Strömberg, 23 J Econ Persp at 128 (cited in note 17).

122 See Judge, $82 \mathrm{U}$ Chi L Rev at 636 (cited in note 8).

123 See Jason Zweig, Like Buffett, Another Folksy Investor Turns Patience into Profit (Wall St J, May 22, 2015), archived at http://perma.cc/LH35-KEDB.

124 See Ari Charney, Betting on the Next Warren Buffett (Investing Daily, June 12, 2012), archived at http://perma.cc/MDN5-S583.

125 See Tim Mullaney, The True Mastermind behind Google's Alphabet? Warren Buffett (MarketWatch, Aug 17, 2015), archived at http://perma.cc/B42S-CMLQ.

126 See Capitalism's Unlikely Heroes (Economist, Feb 7, 2015), archived at http://perma.cc/X9SB-6B82. 
provoke public disclosure, of course, which Judge rightly notes may instead require regulation. ${ }^{127}$

\section{QUESTIONS}

Whether considering either companies like Berkshire and KKR in the acquisitions market or the examples that Professor Judge offers of real estate agents, brokers, funds, and exchanges, traditional theories help evaluate financial intermediation and related institutional arrangements. But Judge's impressive accomplishment is to unite these disparate examples and approaches under the single heading of intermediary influence and explain how it arises, how it is exercised, what some of the costs are, and how participants might respond. As with most such serious intellectual endeavors, the claims are innovative, important, and interesting-and they also raise questions, including the following.

\section{A. Scope and Uniqueness of the Puzzle}

First, Judge posits a prodigious puzzle to explain, but the puzzle may be more modest than it seems. Intermediaries reduce search costs and match end users with providers. ${ }^{128}$ Judge suggests that Internet technology should make searching and matching easier so that intermediary fees should fall. ${ }^{129}$ But she sees the opposite in many financial sectors, suggesting that the puzzle is more pronounced there. ${ }^{130}$ Yet technology is not the only factor that influences the costs of searching and matching that intermediaries can neutralize. Globalization and complexity may increase search costs and complicate matching as well. In many contemporary industrial settings besides finance, supply chains have fragmented and intermediaries have proliferated. Moreover, Internet technology may reduce some costs but raise others. For example, websites that help buyers compare prices promise consumer savings but are funded by referral fees that often skew results so that users need other sites to compare the

127 See Judge, 82 U Chi L Rev at 636 (cited in note 8).

128 Id at 574 (noting that intermediaries "bridge information asymmetries, enable parties to find one another, and otherwise make it easier for parties to overcome the many barriers to transacting").

129 See id at 585 .

130 See id at 585-86 (noting that it is surprising, in view of advances in technology that bridge information asymmetries, that real estate agents are still compensated about as much, in real dollars, as they were in the pre-Internet era). 
comparisons. ${ }^{131}$ More broadly, problems with intermediary influence are not unique to the financial services sector, but plague all markets, including those in which producers or manufacturers exert influence. ${ }^{132}$

\section{B. How to Isolate Influence?}

Second, Judge's examples of intermediaries suggest a degree of influence, but it can be difficult to isolate intermediary influence on laws or norms from the influence of other participants. For example, multiple intermediary sectors may each benefit from a particular outcome, and it is challenging to discern which is exercising the relevant influence in shaping institutional arrangements. After fixed brokerage fees were replaced by competitive rates in 1975 (to give an instance that Judge presents prominently), stockbrokers steered customers toward mutual funds instead of individual stocks because mutual funds were more lucrative-an apparent exercise of stockbroker intermediary influence. ${ }^{133}$

But a number of concurrent influences had the same effect, including advertising by the mutual fund industry, ${ }^{134}$ urging by academic proponents of modern portfolio theory's directive for individuals to diversify, 135 and management consultants who contended that mutual funds were superior to conglomerates as a means of achieving such diversification. ${ }^{136}$ Above all, while Judge posits that the change in fee structure was partly responsible for the shift from individual to institutional stock ownership, that

\footnotetext{
131 See Costly Comparison (Economist, July 11, 2015), archived at http://perma.cc/CEA4-4YLT.

132 See generally George A. Akerlof and Robert J. Shiller, Phishing for Phools: The Economics of Manipulation and Deception (Princeton 2015) (exploring and providing examples of firms distorting markets by appealing to human psychology).

133 Judge, 82 U Chi L Rev at 579-80 (cited in note 8).

134 See Matthew P. Fink, The Rise of Mutual Funds: An Insider's View 146-47 (Oxford 2008) (noting that in 1979 the SEC allowed mutual funds to run meaningful advertisements for the first time since 1933); Lee Gremillion, Mutual Fund Industry Handbook: A Comprehensive Guide for Investment Professionals 32 (Wiley 2005) (describing several ways that mutual funds transformed from a service to a product in the 1980 s and 1990s, including through advertising).

135 For a description of modern portfolio theory's stance on diversification, see Stewart E. Sterk, Rethinking Trust Law Reform: How Prudent Is Modern Prudent Investment Doctrine, 95 Cornell L Rev 851, 858-59 (2010).

136 See Gerald F. Davis, Kristina A. Diekmann, and Catherine H. Tinsley, The Decline and Fall of the Conglomerate Firm in the 1980s: The Deinstitutionalization of an Organizational Form, 59 Am Sociological Rev 547, 563-64 (1994) (discussing changes in business rhetoric about the effectiveness of the conglomerate form).
} 
propensity is a characteristic of a fully developed economy and stock market, independent of brokerage-fee structures. ${ }^{137}$

Or consider auditing: Accountants may enjoy influence to assure that public companies must obtain audits of their financial statements. But many other participants push for such certifications, too, including investors, academics, and regulators who legitimately appreciate the distinct consumer benefits of third-party testing.

As another example, certain intermediary sectors may not be united on how to exercise their influence. The retail moneymanagement industry may be divided between actively managed mutual funds and passively managed index funds. ${ }^{138}$ On some matters, their interests converge and their collective influence is directed to a joint end; in others, intermediary interests diverge, with offsetting results.

\section{Who Really Gains?}

Third, Judge suggests that intermediary influence translates into economic gain for intermediaries, but her illustrations are instances of broader patterns in the economics of intermediaries that often benefit and sometimes cost end users. Take two general models of middlemen. ${ }^{139}$ In one, which is particularly attractive to producers, middlemen bundle delivery of a company's product with their own expert services. The middleman may be both a salesman and a professional. Consider a dentist conducting a checkup who then recommends an implant, or an optometrist giving an eye exam along with a prescription for glasses. Patients ask physicians for advice based on trust, stressing the professional role more than the merchandising one. By training and ethics, the doctor's motivation is to provide the appropriate product; by economic incentive, it is to sell the most expensive good that is appropriate. In most cases, the patient's and physician's goals are aligned, although premium pricing often results and physicians exert influence on institutional arrangements to facilitate such exchanges. Manufacturers of dental implants and eyewear benefit, too, enhancing their pricing

\footnotetext{
137 See Judge, 82 U Chi L Rev at 606-07 (cited in note 8).

138 See generally John C. Bogle, Common Sense on Mutual Funds (Wiley 2d ed 2009) (discussing the benefits and disadvantages of investing in mutual funds versus index funds).

139 See Lawrence A. Cunningham, Patrick Hargreaves, and Torkell Eide, Quality Investing: Owning the Best Companies for the Long Term * $56-58$ (forthcoming 2015) (on file with author).
} 
power while outfitting patients with desired necessities. This pattern parallels how mutual funds have benefited greatly from stockbroker influence.

In a second form of intermediation, customers pay middlemen for the installation of manufactured products-such middlemen include automotive repair shops, electrical contractors, or computer-hardware consultants. Invoices separate parts from labor and customers focus on labor, searching and negotiating for low hourly rates more than examining or haggling over the choice or price of goods. The intermediary's incentives are aligned with customer interests to an extent, since reputations are on the line to make repairs and installations that are safe and reliable. But to the extent that price is a factor, incentives are to recommend the most profitable inputs, which may impair customer interests while helping manufacturers. In the financial services sector, auditors may recommend installing SAP risk management software and rating agencies may endorse SAS stress testing software for banks. When auditors and rating agencies wield influence in such settings, they may generate higher fees for themselves but they also confer pricing power on producers, and the exact distribution of the gains eludes precise measurement.

\section{Industry Structure and Causation}

Finally, Judge implies that the influence of financial intermediaries often manifests itself in industry structure, particularly in oligopolistic features. ${ }^{140}$ Yet it is not always clear whether influence leads to oligopoly or oligopoly leads to influence. ${ }^{141}$ Oligopolies in many sectors often result from products that deliver distinctive consumer benefits. Examples among financial intermediaries are auditors and debt rating agencies, which provide test-based certifications of specialized information that investors cannot verify themselves. An

140 See, for example, Judge, 82 U Chi L Rev at 621-22 \& n 211 (cited in note 8) (discussing the outsized influence exerted by financial intermediaries on the formation of the Volcker Rule, which could have "direct implications for institutional arrangements that [would] affect intermediary profitability and institutional design").

141 See id at 618 ("Two factors - the number of participants in an industry and whether industry participants are collectively organized for other purposes-affect the probability that intermediaries will succeed in promoting favorable institutional arrangements."). 
oligopolistic structure can arise from requirements of professionalization and scale rather than industry influence. ${ }^{142}$

As a broader category, consider producers of "modest essentials"-inputs that cost little in context but are vital. Cheap machine tools used in aerospace manufacturing, enzymes added to food products such as yogurt, and industrial gases employed in processes such as steelmaking all represent a tiny fraction of the user's production costs, but each is essential. ${ }^{143}$ Providers therefore command pricing power, with the result that the industry is dominated by large, reputable firms with oligopolistic industry structures. ${ }^{144}$ Though not exactly middlemen, these providers share something in common with financial intermediaries: when raising capital, both auditing and rating fees are small in context but are nevertheless an unavoidable prerequisite.

Oligopolistic intermediaries do tend to produce competition among rivals that is more benign than vigorous. Firms that possess oligopoly power, especially those that provide relatively uniform products, know that they will be competing for decades to come. ${ }^{145}$ The result is competitive behavior that promotes industry stability more than it leads to price wars among rivals. This is true not only of auditing and rating firms but also of suppliers of industrial gases and makers of other modest essentials. ${ }^{146}$ So the challenging question is whether intermediary influence causes institutional arrangements that create pricing power and high fees, or whether institutional arrangements cause such intermediary influence.

\section{CONCLUSION}

Professor Judge paints a rich picture, using an appealing combination of broad strokes and pointillism to shed new light on an old setting. She offers insightful accounts of specific features of the financial services industry, such as why real estate agents still command premium prices, why stockbrokers were able to

142 See Edgar K. Browning and Mark A. Zupan, Microeconomics: Theory and Applications 310-11, 359 (Wiley 7th ed 2002).

143 Cunningham, Hargreaves, and Eide, Quality Investing at *61 (cited in note 139).

144 See id.

145 See id at *63. See also Browning and Zupan, Microeconomics at 358 (cited in note 142) (describing the "strong mutual interdependence" of firms in an oligopolistic market, meaning that "a firm's actions ... have a noticeable effect on its rivals, and so they are likely to react in some way") (emphasis omitted).

146 See Cunningham, Hargreaves, and Eide, Quality Investing at *60-63 (cited in note $139)$. 
maintain anticompetitive fixed commissions for so long, and why mutual funds proliferate while charging fees that exceed the funds' value to investors. She steps back to explain general features of the financial landscape that give intermediaries potentially excessive pricing power, and catalogues the considerable costs. And she notes potential policy responses, including stimulating private market actors to respond.

In this Essay, I have extended Judge's insights with an illustration from the acquisitions market, depicting one firm (KKR) that epitomizes intermediary influence, in contrast to a rival (Berkshire) — the anti-intermediary par excellence. The juxtaposition affirms the portrait of intermediary influence that Judge paints as well as the potential for correction through lowerpriced competition and fee disclosure she posits.

Judge stresses that her accounts of intermediary influence are partial explanations and that there are degrees of both their influence and their effects. This modesty explains the existence of some of the unanswered questions I have highlighted. The importance of Judge's work is in showing why pursuing answers to such questions is warranted-to gauge the puzzle's size, isolate the specific influence, measure the relative gains, and examine which comes first: intermediary influence that commands high fees or institutional arrangements that condone them. 